DOI: $10.20472 / E S .2018 .7 .1 .002$

\title{
DEVELOPMENT OF A STABLE CORPORATE BANKRUPTCY CLASSIFICATION MODEL: EVIDENCE FROM TAIWAN
}

\section{HONG LONG CHEN}

\begin{abstract}
:
This study constructs a corporate bankruptcy classification model with greater prediction accuracy that can be applied to a wide cross-section of industrial sectors. In Taiwan, development of a bankruptcy classification model for any one industry is difficult because of the small number of bankrupt companies per sector from it. Instead of using industry-relative ratios to stabilize the financial data, this study proposes an approach that combines financial ratio analysis and confirmatory factor analysis with logistic-regression analysis to estimate the probability of financial failure for public corporations. First, Mann-Whitney tests reveal a significant difference in the mean values of bankrupt and nonbankrupt companies for 41 financial ratios. Second, based on these financial ratios, a mathematical modeling procedure is used to develop bankruptcy classification model. Finally, validation of the bankruptcy model is by out-of-sample Type I accuracy, Type II accuracy, and overall correct classification rates. The research results suggest that the proposed modeling approach appears to be robust and relatively insensitive to differential industry effects and time variations.
\end{abstract}

\section{Keywords:}

Bankruptcy; Financial failure; Financial management; Logit models

JEL Classification: G32, G33, M10

\section{Authors:}

HONG LONG CHEN, National University of Tainan, Taiwan, Email: along314@mail.nutn.edu.tw

\section{Citation:}

HONG LONG CHEN (2018). Development of a stable corporate bankruptcy classification model: Evidence from Taiwan. International Journal of Economic Sciences, Vol. VII(1), pp. 16-38., 10.20472/ES.2018.7.1.002 


\section{Introduction}

The purpose of this study is to investigate the implications of corporate bankruptcy in Taiwan and to construct a corporate bankruptcy classification model that can be applied to a wide cross-section of industrial sectors. The importance of a reliable bankruptcy classification model in Taiwan for credit assessment, investment management, and external and internal corporate performance analysis has become increasingly acknowledged as the number of firms facing globalization and economic turbulence increases.

A bankruptcy classification model that combines financial ratio analysis and confirmatory factor analysis with hierarchical logistic-regression analysis yields results which appear to be reliable and accurate. This paper improves the previous bankruptcy work in Taiwan and elsewhere, principally in its longer study period and larger sample size as well as the performance-measurement type of analysis that results in a relatively stable predictive bankruptcy model.

This study proceeds as follows. Section 2 explores the corporate bankruptcy experience in Taiwan. Section 3, "Approach and methods of analysis," describes the sample data and methodology of this study. Section 4, "Research results," depicts the measurementtheory model development, classification model-building and validation. Section 5, "Conclusion," summarizes the research.

\section{Research Background}

Studies of corporate bankruptcy prediction models started in America in the mid-1960s. Since then, using samples of well-established companies, bankruptcy prediction models have progressed from univariate analysis of financial ratios (Beaver, 1966) to multivariate discriminant analysis (e.g., Agarwal and Taffler, 2008; Altman, 1968; Altman et al., 1977; Karels and Prakash, 1987; Pompe and Bilderbeek, 2005), logistic regression analysis (e.g., Arena, 2008; Becchetti and Jaime, 2003; Charitou et al., 2004; Kim and Nabar, 2007; Platt and Platt, 1990; Ohlson, 1980), and intelligent techniques (e.g., Chandra et al., 2009; Lam, 2004).

While numerous academics and practitioners (e.g., Bandopadhyaya and Jaggia, 2001; Dambolena and Khoury, 1980; Johnsen and Melicher, 1994; Ohlson, 1980; Zavgren, 1985) conduct extensive studies and apply sophisticated mathematical methodologies to develop bankruptcy prediction models with purported high predictive power, these models are mostly derived from samples of companies in North America and Europe. For example, based on a sample of 103 failed companies listed on the London Stock Exchange (LSE) in UK, Agarwal and Taffler (2008) use multivariate discriminant analysis 
to compare market-based and accounting-based bankruptcy prediction models, and conclude that little difference exists in their predictive ability.

Li and Miu (2010) combine Altman's (1968) Z-score model and Merton's (1974) marketbased model to develop a hybrid bankruptcy prediction model using a sample of 138 bankrupt and non-bankrupt firms listed on the New York Stock Exchange (NYSE), and claim their model are superior to conventional logistic models. Recently, Charitou et al. (2013) examine the empirical properties of the theoretical Black-Scholes-Merton (BSM) bankruptcy forecasting models based on 1,212 US bankruptcy-filing firms, and conclude that a market-based measure of volatility estimated directly from monthly firm value returns possesses relatively high forecasting accuracy.

More recently, du Jardin (2016) uses financial profiles to estimate the probability of financial failure for French corporations. Based on a sample of 22 companies, he shows how his proposed method improves forecasting accuracy of corporate bankruptcy. Ouenniche and Tone (2017) develop a framework based on data envelopment analysis (DEA) for risk assessment and bankruptcy prediction of companies listed on the London Stock Exchange, and conclude that DEA is a valuable tool for bankruptcy evaluation and benchmarking.

Nonetheless, previous studies (e.g., Claessens et al., 2000; La Porta et al., 1999; Yeh et al., 2001) reveal considerable differences in corporate governance between East Asia and North America and Europe. One difference, for example, is that in East Asia, corporate ownership structure is less dispersed, and the ultimate controllers frequently increase their influence through pyramid structures and cross-holdings. Another is that corporate directors and controlling shareholders in East Asia commonly pledge their shares as collateral for bank loans to obtain extra shares. Consequently, bankruptcy models derived from samples of companies in North America and Europe may not be applicable to firms in East Asia.

Several recent bankruptcy studies in Taiwan have demonstrated the ability of correctly classifying companies as likely to be bankrupt or not, despite relatively short study periods and small samples of companies. For example, Tsai (2012) examines 37 bankrupt companies and a matched sample of 37 non-bankrupt companies using logistic regression analysis. His sample of companies failed during the six-year period, 20032008, and all were listed on the Taiwan Stock Exchange. The overall correct classification accuracy one year prior to bankruptcy from Tsai's (2012) 14-variable logit model is $80.82 \%$.

Subsequent work of Lin et al. (2013) extends the work of Tsai (2012) in several ways. Their sample is significantly larger with 52 bankrupt companies and 52 matched nonbankrupt companies, covering 2000-2008. Lin et al. (2013) perform Locally Linear Embedding (LLE) algorithm to compute the projection of the 16 financial variable data 
into a lower-dimensional space to reveal hidden patterns in the data that are used to develop a bankruptcy classification model. The overall classification accuracy from Lin et al.'s (2013) model is fairly good with one year prior to bankruptcy classification accuracy of $82.61 \%$, which slightly outperforms Tsai's (2012) model by $1.79 \%$.

Recently, Chen (2014) suggests a hybrid approach combining PCA, Particle Swarm Optimization (PSO), and support vector machines (SVM) for corporate bankruptcy prediction. His sample consisted of 34 bankrupt firms and 34 matched non-bankrupt firms, covering 1999-2006. Chen (2014) concludes that PSO-SVM is a viable alternativeestimating technique, with one year prior to bankruptcy classification accuracy of $72.5 \%$. A subsequent study, Liang et al. (2016), examines the classification performance of several different bankruptcy models and concludes that SVM has the best performance while combining with financial ratios and corporate governance indicators.

As mentioned, despite the panoply of studies on corporate bankruptcy predictions, these studies primarily focus on bankruptcy in North America and Europe (e.g., Bandopadhyaya and Jaggia, 2001; Charitou et al., 2013; Johnsen and Melicher, 1994; Ohlson, 1980). Whilst prior research suggests substantial differences in corporate governance between East Asia and North America and Europe (e.g., Claessens et al., 2000; La Porta et al., 1999; Yeh et al., 2001), bankruptcy forecasting models derived from samples of companies in North America and Europe may not be applicable in East Asia.

Although some recent studies in Taiwan are devoted to development of bankruptcy prediction models (e.g., Chen, 2014; Lin et al., 2013; Tsai, 2012), the validation results of examining the prediction accuracy of these models are somewhat disappointing. Possible explanations of the low predictive ability include significant differential industry effects due to a wide cross-section of industrial sectors with a relatively small number of companies per sector as well as financial data instability over time. The objective of this study is, therefore, to propose a methodology for developing a class of stable bankruptcy models that alleviate the data instability problem and differential industry effects.

\section{Approach and Methods of Analysis}

\section{The Data}

Our sample of bankrupt companies includes companies that encountered bankruptcy or liquidation events over the period 1989-2012. The date of failure is the date of delisting from the Taiwan Stock Exchange. We exclude transportation, utilities, and financial services corporations, including banks, insurance companies, brokerage firms, etc., since corporations in these industries are structurally different that have different financial failure environments (Charitou et al., 2004; Ohlson, 1980). We also exclude companies that do not have complete data sets available on the Taiwan Economic Journal (TEJ) database. This results in 74 companies included in bankruptcy between 1989 and 2012, 
ranging in size from $\$ 0.4$ million to $\$ 1,191.0$ million in five-year-average assets.

To isolate key variables that distinguish bankrupt from nonbankrupt companies, we select a sample of nonbankrupt companies from TEJ to match the bankrupt companies. ${ }^{1}$ The nonbankrupt companies have the same $\mathrm{TSIC}^{2}$ code, nearly equal average asset size for five years as the matched bankrupt firm. ${ }^{3}$ The 74 nonbankrupt companies range in size from $\$ 9.1$ million to $\$ 1,464.9$ million in five-year-average assets. The average sizes of the bankrupt and nonbankrupt firms are $\$ 224.1$ million and $\$ 225.1$ million, respectively. The result of a paired-samples t-test further confirms an insignificant difference between the means of the bankrupt and nonbankrupt firms with a p-value of 0.95 .

We compute the financial ratios and industry averages using data from TEJ. To obtain an industry average that is comparable across industries, we use two-digit TSIC codes. Companies with the same first two-digit NAICS code are classified in the same industry. ${ }^{4}$

Table 1 lists the industry affiliation of the bankrupt group. The 74 bankrupt firms come from 22 sectors, including cement, food, rubber, textiles, electric, machinery, electronics and cables, glass and ceramics, paper and pulp, iron and steel, automotive, construction and building materials, tourism, retail, miscellaneous, chemicals, computer and peripheral equipment manufacturing, optoelectronics, internet-based workplace communications, electronic components, electrical distribution, information services, and miscellaneous (electronics). The 22 sectors include 610 companies.

Table 1: Industry representation - Bankrupt company sample between 1989 and 2012

\begin{tabular}{clcc}
\hline $\begin{array}{c}\text { Code } \\
\text { No. }\end{array}$ & Industry & $\begin{array}{c}\text { No. of Bankrupt } \\
\text { Firms }\end{array}$ & $\begin{array}{c}\text { No. of Firms in } \\
\text { the Industry }\end{array}$ \\
\hline 01 & Cement & 1 & 7 \\
02 & Food & 9 & 20 \\
03 & Rubber & 1 & 10 \\
04 & Textiles & 8 & 47 \\
05 & Electric Machinery & 3 & 37 \\
06 & Electronics and cables & 4 & 14 \\
08 & Glass and Ceramics & 1 & 4 \\
09 & Paper and Pulp & 1 & 7
\end{tabular}

${ }^{1}$ A volume of previous studies (e.g., Altman, 1968; Altman and Izan, 1983; Beaver, 1966; Charitou et al., 2004; Dambolena and Khoury, 1980; Izan, 1984; Platt and Platt, 1990) use paired-sample analysis, with size and industry type as bases for pairing, to isolate key variables.

2 The Taiwan Standard Industrial Classification (TSIC) was developed under the auspices of the Office of the Directorate General of Budget, Accounting \& Statistics of Executive Yuan.

${ }^{3}$ Instead of using asset size one year before bankruptcy, we use average asset size for five years prior to bankruptcy. This is a more rigorous approach that results in better-matched nonbankrupt firms.

${ }^{4}$ The purpose of computing industry averages is to perform industry-relative analysis to further validate our proposed classification model. An industry-relative ratio is a company's financial ratio relative to the mean value for that ratio for the industry. 


\begin{tabular}{llcc}
10 & Iron and Steel & 6 & 29 \\
12 & Automotive & 1 & 5 \\
14 & Construction and Building Materials & 10 & 40 \\
16 & Tourism & 1 & 10 \\
18 & Retail & 2 & 10 \\
20 & Miscellaneous & 5 & 36 \\
21 & Chemicals & 1 & 25 \\
25 & Computer and Peripheral Equipment & 5 & 55 \\
26 & Manufacturing & 1 & 70 \\
27 & Internet-based Workplace & 2 & 37 \\
28 & Communications & & 80 \\
29 & Electronic Components & 5 & 22 \\
30 & Information Services & 3 & 12 \\
31 & Miscellaneous (Electronics) & 2 & 33 \\
\hline & Total & 2 & 610 \\
\hline
\end{tabular}

Source: Taiwan Economic Journal.

The final data sets, composed of 148 bankrupt and nonfailed companies between 1989 and 2012, were used to build our measurement-theory model for bankruptcy. We then split the data sets into two subsamples: the in-sample (ex-post) data and the out-ofsample (ex-ante) data. ${ }^{5}$ We use the in-sample data to build bankruptcy classification models; the data includes information for 80 bankrupt and nonbankrupt firms from 1989 to 2003. We use the out-of-sample data, composed of 68 bankrupt and nonfailed companies between 2004 and 2012, to study the predictive ability of the models.

\section{Variables}

Based on an extensive review of the literature and in an effort to generate a more comprehensive assessment, we include 60 financial ratios that are potential bankruptcy determinants. The 60 ratios encompass five different aspects of financial conditions or operating results, including short-term liquidity performance, capital structure and solvency, profitability performance, operating performance, and cash flow performance.

Short-term Liquidity Performance is composed of nine financial ratios (Table 2) based on prior research. The representative studies include Altman (1968), Altman et al. (1977),

${ }^{5}$ The division ratio for in-sample (ex-post) data and the out-of-sample (ex-ante) data generally varies from 1:1 to 9:1. A $1: 1$ ratio is commonly considered to be a more robust validation, since it includes relatively more data for testing the model. In this study, we adopted a 1:1 ratio for in-sample and the out-of-sample data. However, due to the distribution of sample firms between 1989 and 2012, we were not able to obtain an exact 1:1 ratio from any given year. Therefore, we chose the year 2003 to divide the sample into in-sample and out-sample firms, generating a 54:46 ratio that is the closest to a 1:1 ratio. 
Beaver (1966), Becchetti and Jaime (2003), Casey and Bartczak (1985), Frydman et al (1985), Li and Miu (2010), Karels and Prakash (1987), Mensah (1984), Ohlson (1980), Platt and Platt (1990), and Zavgren (1985). Sample ratios are working capital to total assets, current ratio, acid-test ratio, and accounts receivable turnover.

Table 2: Taxonomy of financial ratios as bankruptcy-predictor attributes, KolmogorovSmirnov tests, and Mann-Whitney tests

\begin{tabular}{|c|c|c|}
\hline Financial Ratios & $\begin{array}{c}\text { Kolmogorov- } \\
\text { Smirnov Statistic } \\
\qquad N=148\end{array}$ & $\begin{array}{l}\text { Mann-Whitn } \\
\text { Statistic } N=1\end{array}$ \\
\hline \multicolumn{3}{|l|}{ Short-term Liquidity Performance } \\
\hline Working capital to total assets & $0.53^{* \star *}$ & $1,139^{\star \star \star}$ \\
\hline Current ratio & $0.21^{\star \star \star}$ & $1,097^{\star \star \star}$ \\
\hline Acid-test ratio & $0.30^{* *}$ & $1,177^{\star \star \star}$ \\
\hline Accounts receivable turnover & $0.30^{* * *}$ & $2,195^{*}$ \\
\hline Inventory turnover & $0.47^{\star \star \star}$ & 2,694 \\
\hline Day's sales in accounts receivables & $0.52^{* * *}$ & $3,466^{\star \star}$ \\
\hline Day's sales in inventory & $0.43^{* \star *}$ & 3,065 \\
\hline Day's purchase in accounts payable & $0.38^{* * *}$ & $3,558^{\star \star}$ \\
\hline Working capital & $0.22^{\star \star \star}$ & $1,257^{\star \star \star}$ \\
\hline \multicolumn{3}{|l|}{ Capital Structure and Solvency } \\
\hline Market value of equity to total debts & $0.16^{\star \star \star}$ & $574^{\star \star \star}$ \\
\hline Retained earnings to total assets & $0.53^{* \star *}$ & $588^{\star * *}$ \\
\hline $\begin{array}{l}\text { Earnings before interest and taxes to } \\
\text { total assets }\end{array}$ & $0.46^{\star \star \star}$ & $1,327^{\star \star *}$ \\
\hline Total debt to equity & $0.42^{* \star *}$ & 2,901 \\
\hline Total debt ratio & $0.53^{* * *}$ & $4,973^{\star * \star}$ \\
\hline Long-term debt to equity & $0.44^{\star \star \star}$ & 2,505 \\
\hline Equity to total debt & $0.14^{\star \star \star}$ & $503^{\star * *}$ \\
\hline Fixed assets to equity & $0.43^{\star \star \star}$ & 2,520 \\
\hline Current liabilities to total liabilities & $0.12^{\star \star \star}$ & 3,082 \\
\hline Times interest earned & $0.48^{\star \star \star}$ & $1,358^{* \star *}$ \\
\hline Degree of operation leverage & $0.45^{\star \star \star}$ & $2,056^{\star *}$ \\
\hline Degree of financial leverage & $0.35^{\star \star \star}$ & $1,753^{* \star *}$ \\
\hline Degree of combined leverage & $0.35^{\star \star \star}$ & $2,000^{* *}$ \\
\hline \multicolumn{3}{|l|}{ Profitability Performance } \\
\hline Gross profit margin & $0.18^{* \star *}$ & $1,345^{\star * \star}$ \\
\hline Operating profit margin & $0.52^{\star \star \star}$ & $1,264^{* \star *}$ \\
\hline Net profit margin & $0.52^{\star \star *}$ & $1,071^{* \star *}$ \\
\hline Return on assets & $0.53^{* \star \star}$ & $1,156^{* \star *}$ \\
\hline Return on long-term debt and equity & $0.38^{\star \star \star}$ & $1,681^{* \star}$ \\
\hline
\end{tabular}


Net income from continuing operations (NI)

Fully Diluted EPS

$0.15^{* * *}$

$537^{\star \star *}$

Operating Performance

Sales to total assets

Sales to cash and equivalents

Sales to receivables

Sales to inventories

Sales to working capital

Sales to fixed assets

Sales to other assets

Sales to short-term liabilities

Invested capital turnover

Equity turnover

Capital intensity

Accumulated depreciation as a

percent of gross plant assets

Depreciation expenses as a percent

of gross plant

Depreciation expenses as a percent

of sales

Selling to sales

Research and development to sales

Cost of goods sold to sales

Operating expense to sales

Sales growth

Gross profit growth

Net profit growth

Equity growth rate

Cash Flow Performance

Cash to interest payment

Cash long-term debt coverage

Cash flow to total debt

Cash flow liquidity ratio

Cash flow margin

Approximate conversion period

Cash conversion cycle

Cash to current assets

Cash to current liabilities
$0.50^{* * *}$

$1,046^{* * *}$

$0.16^{* * *}$

$2,113^{*}$

$0.40^{* * *}$

$3,584^{* * *}$

$0.48^{* * *}$

2,515

$0.47^{\star \star \star}$

$0.29^{* \star \star}$

2,749

$0.40^{\star * \star}$

$1,830^{* * *}$

$0.45^{\star * *}$

2,362

$0.17^{* * *}$

2,230

$0.30^{* * *}$

$1,070^{\star * \star}$

$0.44^{* * *}$

2,618

$0.40^{* \star *}$

2,582

2,362

$0.42^{\star \star \star}$

3,200

$0.45^{\star * \star}$

3,046

$0.45^{\star \star \star}$

$3,633^{\text {** }}$

$0.25^{* * *}$

3,082

$0.28^{\star \star \star}$

$3,474^{*}$

$0.18^{* * *}$

$4,132^{* * *}$

$0.49^{* * *}$

$3,968^{* \star \star}$

$0.17^{* \star *}$

$1,599^{\text {***}}$

$0.20^{\star * \star}$

$1,934^{* *}$

$0.44^{* * *}$

3,126

$0.34^{\star \star *}$

$2,101^{\star}$

$0.44^{\text {***}}$

$0.44^{* \star *}$

$1,819^{\star \star *}$

$0.20^{\text {***}}$

$1,897^{* *}$

$0.31^{\text {*** }}$

$1,238^{* * *}$

$0.53^{\text {***}}$

$1,097^{* \star *}$

$0.43^{\star * *}$

$1,659^{\text {***}}$

$0.41^{* * *}$

3,168

$0.23^{\star \star \star}$

3,059

$0.39^{* \star \star}$

Source: Own calculations based on financial statements from Taiwan Economic Journal. ${ }^{*} P<0.05,{ }^{* *} P$ $<0.01$, and ${ }^{* * *} P<0.001$. 
Capital Structure and Solvency is composed of 13 financial ratios (Table 2). The representative studies include Altman et al. (1977), Becchetti and Jaime (2003), Castanias (1983), Charitou et al. (2004), Evans (2003), Foreman (2003), and Ohlson (1980). Sample ratios include market value of equity to total debts, retained earnings to total assets, total debt to equity, and times interest earned.

Profitability Performance is composed of seven financial ratios (Table 2). The representative studies include Altman (1968), Altman et al. (1977), Beaver (1966), Becchetti and Jaime (2003), Charitou et al. (2004), Claessens et al. (2003), Foreman (2003), Karels and Prakash (1987), Kim and Nabar (2007), Li and Miu (2010), and Platt and Platt (1990). Sample ratios are net profit margin, return on assets, return on longterm debt and equity, and net income from continuing operations ( $\mathrm{NI})$.

Operating Performance consists of 22 financial ratios (Table 2). The representative studies include Altman (1968), Altman et al. (1977), Becchetti and Jaime (2003), Beaver (1966), Casey and Bartczak (1985), Charitou et al. (2004), Karels and Prakash (1987), and $\mathrm{Li}$ and Miu (2010). Sample ratios include sales to total assets, sales to cash and equivalents, equity turnover, and sales growth.

Cash Flow Performance consists of nine financial ratios (see Table 2). The representative studies are Altman et al. (1977), Beaver (1966), Castanias (1983), Frydman et al. (1985), Karels and Prakash (1987), Mensah (1984), and Platt and Platt (1990). Sample ratios are cash to interest payment, cash long-term debt coverage, cash flow to total debt, and cash flow liquidity ratio.

Table 2 lists the taxonomy of financial ratios, Kolmogorov-Smirnov tests, and MannWhitney tests for one year prior to bankruptcy for 148 bankrupt and nonbankrupt companies. We use Mann-Whitney tests for the 60 financial ratios because the data are not normally distributed based on the results of Kolmogorov-Smirnov tests, which deem data abnormally distributed when the probability value is smaller than the threshold value of 0.05 .

As the table shows, a significant difference exists in the mean values of bankrupt and nonbankrupt companies for 41 of the 60 ratios in one year before bankruptcy. Significance of difference in means exists when the probability of the Mann-Whitney test is smaller than 0.05 . Therefore, based on the results of the Mann-Whitney tests, we include 41 ratios for further study.

\section{Method of Analysis}

This study asserts that with an optimal combination of independent variables that correctly specify the bankruptcy model, it would stabilize the model and, thus, alleviate the data instability problem and differential industry effects. Now the question is how to obtain an optimal mix of independent variables for the model. 
To answer this question, this study proposes a mathematical modeling procedure to develop bankruptcy classification models. The procedure is based on a combined confirmatory factor analysis and logistic regression analysis, starting from the following general factor analysis model:

$$
X=\Lambda_{x} \xi+\delta
$$

where $X$ is the $p \times 1$ vector of ratio variables with $p$ equal to the number of ratio variables at time $t, \xi$ is the latent variables such as Short-term Liquidity Performance, Capital Structure and Solvency, Profitability Performance, Operating Performance, and Cash Flow Performance, $\Lambda_{x}$ is a $p \times k$ factor loading matrix with $k$ equal to the number of latent variables, and $\delta$ is the $p \times 1$ vector of random errors.

Maximum likelihood (ML) estimation using iterative methods is utilized to obtain the optimum values of $\Lambda_{\mathrm{x}}$, minimizing the values of the elements in the residual matrix. The discrepancy function for the ML method is:

$$
F_{M L}=\ln \left|\Lambda_{x} \Psi \Lambda_{x}^{\prime}+\Theta\right|-\ln |S|+\operatorname{Trace}\left[S\left(\Lambda_{x} \Psi \Lambda_{x}^{\prime}+\Theta\right)^{-1}\right]-p
$$

where $\Psi$ is the common factor covariance matrix, $\Theta$ is the error variance matrix, $S$ is sample variance-covariance matrix, and $P$ is the number of ratio variables in the covariance matrix.

Equations (1) and (2) are used to develop a performance-measurement model for bankruptcy based on the Short-term Liquidity Performance, Capital Structure and Solvency, Profitability Performance, Operating Performance, and Cash Flow Performance constructs. To ensure the stability and validity of the measurement model, items (ratios) with factor loadings smaller than 0.50 are deleted. Further deletion of items for refining the measurement model is assessed through repeated model fittings based on an examination of the comparative fit index (CFI), Tucker-Lewis index (TLI), and composite reliability (CR), the average variance extracted (AVE) along with the root mean square error of approximation (RMSEA) procedure as the following:

$$
\begin{aligned}
& C F I=1-\left(\chi_{r}^{2}-d f_{r}\right) /\left(\chi_{b}^{2}-d f_{b}\right) \\
& T L I=1-\left(\frac{\chi_{b}^{2}}{d f_{b}}-\frac{\chi_{r}^{2}}{d f_{r}}\right) /\left(\frac{\chi_{b}^{2}}{d f_{b}}-1\right)
\end{aligned}
$$

where $\chi_{r}^{2}$ and $d f_{r}$ are the chi-square and degree of freedom for the research model being evaluated, and $\chi_{b}^{2}$ and $d f_{b}$ are the chi-square and degree of freedom for the baseline model. 


$$
\begin{aligned}
& C R=\left(\sum_{i=1}^{p} F L_{i}\right) /\left(\sum_{i=1}^{p} F L_{i}-\sum_{i=1}^{p} e_{i}\right) \\
& A V E=\sum_{i=1}^{p} F L_{i} / p
\end{aligned}
$$

where $F L_{i}, e_{i}$, and $p$ are the factor loading, error variance, and the number of items of the latent construct being evaluated. The equation for RMSEA is:

$$
R M S E A=\sqrt{\chi_{r}^{2}-d f_{r} / N-1}
$$

where $N$ is the sample size. Based on the performance-measurement model for bankruptcy, we conduct a hierarchical logistic-regression analysis using a maximum Nagelkerke R-squared improvement procedure to develop optimal bankruptcy classification models. The reason we use logistic analysis is because it makes no assumptions concerning multivariate, normally distributed variables or equal-dispersion matrices (Ohlson, 1980; Zavgren, 1983), Logistic analysis is considered as less demanding requirements and is the most popular conditional-probability method (Balcaen and Ooghe, 2006). The general form of the logistic model is:

$$
\operatorname{Pr}=1 /(1+\exp -(\alpha+\beta X))
$$

where $\operatorname{Pr}$ is the probability of bankruptcy of a firm going bankrupt at time $(t+1), \mathrm{X}$ is the vector of ratio variables at time $t$ from the performance-measurement model, $\alpha$ is the vector of intercepts, and $\beta$ is the vector of coefficients.

\section{Research Results}

\section{Analysis of Bankruptcy Measurement Model}

Table 3 lists those financial ratios ultimately retained for the performance-measurement model for bankruptcy. Figure 1 depicts the performance-measurement model, which is congeneric, has five latent constructs that correlate with all other constructs.

Table 3: Financial ratios included in the performance-measurement model for bankruptcy classification

\begin{tabular}{llll}
\hline Variable & $\begin{array}{c}\text { Factor } \\
\text { Loadings }\end{array}$ & $\begin{array}{c}\text { Overall } \\
\text { Correct }\end{array}$ & Measure \\
\hline Short-term Liquidity Performance & \\
0.85 & $75.0 \%$ & Working capital to total assets (WC/TA) \\
0.96 & $73.0 \%$ & Working capital (WC) \\
\hline
\end{tabular}

Capital Structure and Solvency

$0.94 \quad 81.1 \% \quad$ Market value of equity to total debts 
(MVE/TD)

$0.96 \quad 80.4 \% \quad$ Equity to total debt (E/TD)

Profitability Performance

0.54

$64.9 \%$ Gross profit margin (GPM)

0.57

$80.4 \% \quad$ Net income from continuing operations (NI)

Operating Performance

$0.58 \quad 57.4 \% \quad$ Sales to total assets (S/TA)

$0.99 \quad 73.0 \% \quad$ Sales to short-term liabilities (S/STL)

Cash Flow Performance

0.99

$73.0 \%$ Cash flow liquidity ratio (CFLR)

0.90

$64.2 \% \quad$ Cash to current liabilities (C/CL)

Source: Own calculations. a Classification of one-year period before bankruptcy.

Figure 1: Performance-measurement model for bankruptcy classification. Note: The model chi-square $\left(\chi^{2}\right)$ /degrees of freedom $=1.526 ; \mathrm{CFI}=0.990 ; \mathrm{TLI}=0.977 ;$ and $\mathrm{RMSEA}=0.060$.

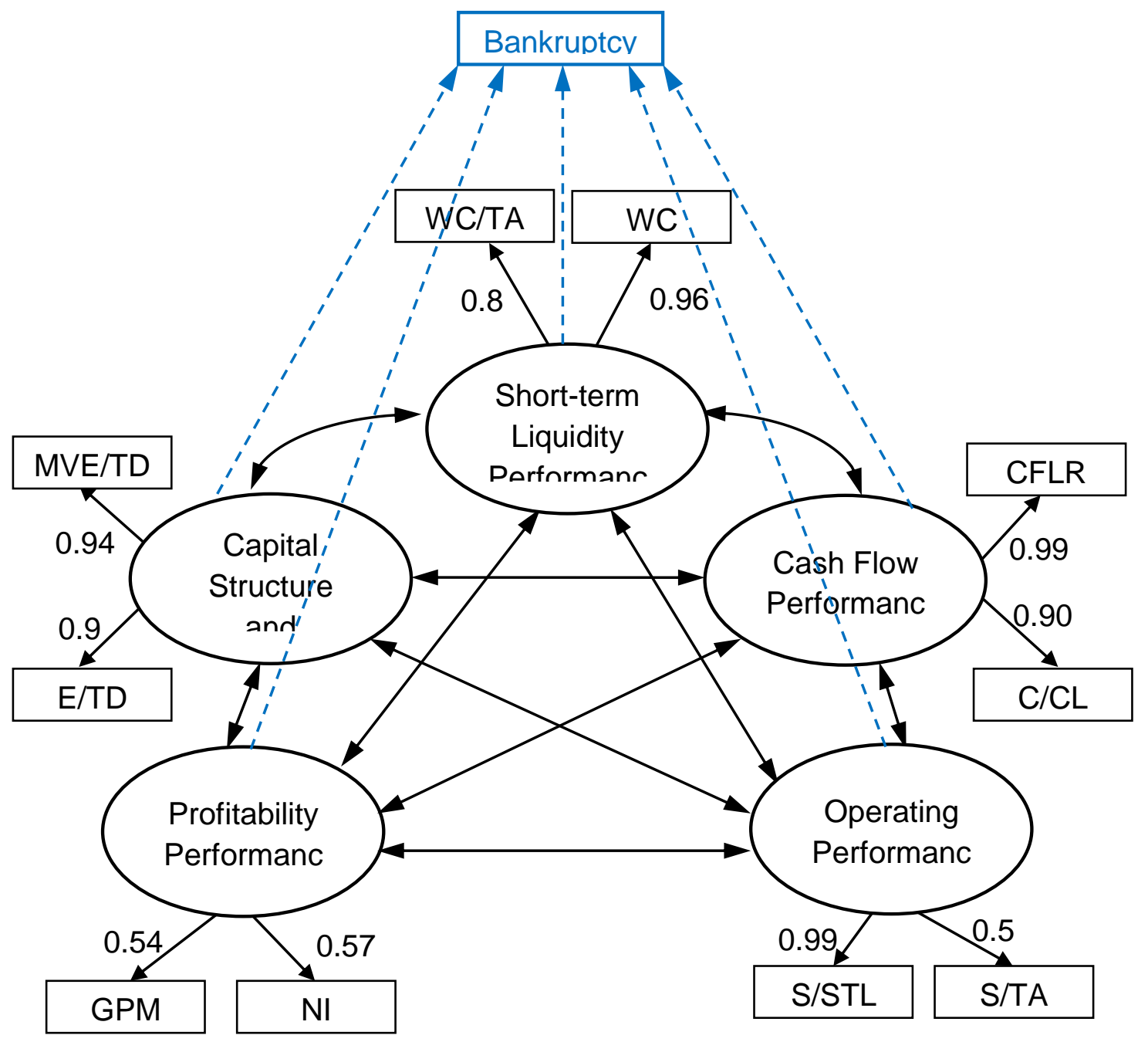

Source: Own calculations. 
To test for convergent validity of the performance model, we use the factoring loadings (equations 1 and 2) and composite reliability (equation 5) to evaluate the relative convergence among ratio measures. High loadings on a factor indicate that they converge on a common point, suggesting high convergent validity (Harrington, 2008). Thus, those factor loadings that are smaller than the threshold value of 0.50 are removed from the model. As Figure 1 and Table 3 show, the retained factor loadings range from 0.54 to 0.99 and are significant at the $p<0.01$ level, suggesting the existence of convergent validity.

Further, a high $\mathrm{CR}$ indicates that the ratio measures consistently represent the same latent construct, suggesting the existence of convergent validity (Kline, 2010). As the bottom of Table 4 shows, the respective CR values of Short-term Liquidity Performance, Capital Structure and Solvency, Profitability Performance, Operating Performance, and Cash Flow Performance are 0.666, 0.669, 0.677, 0.650, and 0.665, which are larger than the threshold value of 0.60 (Kline, 2010). This confirms an adequate convergence for all the constructs.

Table 4: Squared correlations, average variance extracted, and composite reliability of the bankruptcy performance-measurement model

\begin{tabular}{|c|c|c|c|c|c|}
\hline Variable & 1 & 2 & 3 & 4 & 5 \\
\hline 1. Short-term Liquidity Performance & 1 & & & & \\
\hline 2. Capital Structure and Solvency & 0.151 & 1 & & & \\
\hline 3. Profitability Performance & 0.298 & 0.361 & 1 & & \\
\hline 4. Operating Performance & 0.089 & 0.001 & 0.230 & 1 & \\
\hline 5. Cash Flow Performance & 0.013 & 0.213 & 0.171 & 0.061 & 1 \\
\hline Average Variance Extracted & 0.822 & 0.903 & 0.381 & 0.658 & 0.895 \\
\hline Composite Reliability & 0.666 & 0.669 & 0.677 & 0.650 & 0.665 \\
\hline
\end{tabular}

Source: Own calculations.

To test for discriminant validity of each latent construct, we compare the average variance extracted (AVE) (equation 6) values for any two constructs with the square of the correlation estimate between the constructs (Fornell and Larcker, 1981). As seen from Table 4, the AVE value of Short-term Liquidity Performance is 0.822 that is greater than the square of the correlation estimate between Short-term Liquidity Performance and any of the other constructs.

The AVE value of Capital Structure and Solvency is 0.903 that is greater than the square 
of the correlation estimate between Capital Structure and Solvency and any of the other constructs, and likewise the AVE values of Profitability Performance and Operating Performance are all greater than the square of their respective correlation estimates. This comparison suggests that any of latent constructs in the measurement model explains more of the variance in its ratio measures than it shares with other latent constructs, providing strong evidence of discriminant validity for the measurement model.

The final analysis results of the performance-measurement model suggest an adequate fit with the data. The model chi-square $\left(\chi^{2}\right)$ /degrees of freedom $=1.526$, which is smaller than the threshold value of 2.000 suggested by Kline (2010); CFI $=0.990$ (equation 3) and $\mathrm{TLI}=0.977$ (equation 4) are both higher than the threshold value of 0.900 suggested by Bentler (1990); and RMSEA = 0.060 (equation 7) is smaller than the threshold values of 0.080 (Kline, 2010; Lee, 2007). The analysis results suggest the stability and validity of the measurement model.

\section{The Bankruptcy Model}

Using hierarchical logistic-regression analyses (equation 8) by a maximum Nagelkerke Rsquared improvement procedure, we further develop the bankruptcy measurement-theory model into optimal bankruptcy classification models from the 80 (in-sample) bankrupt and nonbankrupt companies between 1989 and 2003. Table 5 reports the model-building results.

Table 5: Bankruptcy classification models created with the hierarchical logistic regression using a maximum Nagelkerke R-squared improvement

\begin{tabular}{|c|c|c|c|c|c|c|c|}
\hline \multirow{2}{*}{$\begin{array}{l}\text { Variables and } \\
\text { Sources }\end{array}$} & \multicolumn{2}{|c|}{ Model 1} & \multicolumn{2}{|c|}{ Model 2} & & \multicolumn{2}{|c|}{ Model 10} \\
\hline & B & S.E. & $B$ & S.E & .. & $\mathrm{B}$ & S.E \\
\hline Intercept & $1.435^{\star \star \star}$ & 0.411 & $1.550^{\star * *}$ & 0.439 & . . & 0.532 & 0.858 \\
\hline Step 1: E/TD & $-1.897^{\star \star \star}$ & 0.421 & $-2.232^{\star \star \star}$ & 0.492 & . & -2.290 & 1.143 \\
\hline Step 2: C/CL & & & $0.886^{* *}$ & 0.341 & . & 2.331 & 1.684 \\
\hline Step 3: NI a & & & & & .. & $-2.578^{* *}$ & 0.957 \\
\hline Step 4: WC/TA & & & & & .. & -1.632 & 1.940 \\
\hline Step 5: WC ${ }^{b}$ & & & & & .. & 0.224 & 0.276 \\
\hline Step 6: MVE/TD & & & & & . & 0.470 & 0.917 \\
\hline Step 7: GPM & & & & & .. & 1.871 & 2.343 \\
\hline Step 8: S/TA & & & & & .. & 0.029 & 1.837 \\
\hline Step 9: S/STL & & & & & .. & 0.038 & 0.597 \\
\hline Step 10: CFLR & & & & & . & -0.916 & 0.978 \\
\hline-2 Log likelihood & 64.405 & & 60.952 & &. & 43.719 & \\
\hline Nagelkerke $R^{2}$ & 0.588 & & 0.619 & & $\therefore$ & 0.758 & \\
\hline Type I Accuracy (\%) & 82.500 & & 82.500 & & & 95.000 & \\
\hline
\end{tabular}


Source: Own calculations.

As the table shows, the optimal bankruptcy classification model at step 1 (Model 1) is the one with the E/TD variable, where the model deviance between the observed and predicted values of the data is 64.405 , and $58.80 \%$ of the variation in the data is explained; the corresponding Type I, Type II, and overall correct classification rates are $82.50 \%, 75.00 \%$, and $78.75 \%$.

At step 2, the optimal bankruptcy classification model (Model 2), composed of the E/TD and $\mathrm{C} / \mathrm{CL}$ variables, explains $61.90 \%$ of the variation in the data, which is $3.10 \%$ more than that of Model 1; the deviance is reduced from 64.405 to 60.952 . The respective Type I, Type II, and overall correct classification rates are $82.50 \%, 75.00 \%$, and $78.75 \%$, which, however, are not improved.

The corresponding added variables to Models 3 to 10 are NI, WC/TA, WC, MVE/TD, GPM, S/TA, S/STL, and CFLR. At step 10, the optimal bankruptcy classification model (Model 10) explains $75.80 \%$ of the variation in the data, where the model deviance is reduced to 43.719. The respective Type I, Type II, and overall correct classification accuracy are $95.00 \%, 87.50 \%$, and $91.25 \%$.

As the Nagelkerke R-squared values are all improved by adding more variables until Model 10, this study selects Model 10 as the optimal bankruptcy classification model. The general form of our logit bankruptcy classification model (Model 10) is summarized as follows:

$$
\operatorname{Pr}_{i}=1 /\left(1+\exp -\left(B_{0}+B_{1} X_{S L P}+B_{2} X_{C S S}+B_{3} X_{P P}+B_{4} X_{O P}+B_{5} X_{C F P}\right)\right)
$$

where the cut-off point is 0.5 , and

$$
\begin{aligned}
& \operatorname{Pr}_{i}= \text { probability of bankruptcy of the th firm } \\
& X_{S L P}=\begin{array}{l}
\text { Short-term Liquidity Performance measured by working capital to total } \\
\text { assets (WC/TA) and working capital (WC) }
\end{array} \begin{array}{l}
\text { Capital Structure and Solvency measured by market value of equity to } \\
\text { total debts (MVE/TD) and equity to total debt (E/TD) }
\end{array} \\
& X_{C S S}=\begin{array}{l}
\text { Profitability Performance measured by gross profit margin (GPM) and } \\
\text { net income from continuing operations (NI) }
\end{array} \\
& X_{O P=} \begin{array}{l}
\text { Operating Performance measured by sales to total assets (S/TA) and } \\
\text { sales to short-term liabilities (S/STL) }
\end{array}
\end{aligned}
$$




$$
\begin{aligned}
X_{C F P}= & \text { Cash Flow Performance measured by cash flow liquidity ratio (CFLR) } \\
& \text { and cash to current liabilities }(\mathrm{C} / \mathrm{CL})
\end{aligned}
$$

\section{Classification Accuracy}

Type I, Type II, and overall correct classification accuracy evaluate the in-sample and out-of-sample accuracy. The left-hand side of Panel A of Table 6 summarizes the insample and out-of-sample classification accuracy of Model 10 one-year period before bankruptcy. As Panel A shows, the respective Type I, Type II, and overall in-sample classification accuracy of the model are $95.00 \%$ (38 of 40 correctly classified), $87.50 \%$ (35 of 40 correctly classified), and $91.25 \%$ (73 of 80 correctly classified), whist those outof-sample classification accuracy of the model are $94.12 \%$ (32 of 34 correctly classified), $91.18 \%$ (31 of 34 correctly classified), $92.65 \%$ (63 of 68 correctly classified).

\begin{tabular}{|c|c|c|c|c|}
\hline Group & \multicolumn{4}{|c|}{ Percentage Correctly Classified } \\
\hline \multirow{3}{*}{ Panel A } & \multirow{2}{*}{\multicolumn{2}{|c|}{ Model 10}} & \multirow{2}{*}{\multicolumn{2}{|c|}{$\begin{array}{l}\text { Model Created only with Equation } \\
\qquad(8)^{a}\end{array}$}} \\
\hline & & & & \\
\hline & $\begin{array}{l}\text { In-sample, } \\
\text { 1989-2003 }\end{array}$ & $\begin{array}{l}\text { Out-of-sample, } \\
2004-2012\end{array}$ & $\begin{array}{l}\text { In-sample, } \\
\text { 1989-2003 }\end{array}$ & $\begin{array}{l}\text { Out-of-sample, 2004- } \\
2012\end{array}$ \\
\hline Failures & 95.00 & 94.12 & 97.5 & 73.53 \\
\hline Survivors & 87.50 & 91.18 & 97.5 & 82.53 \\
\hline Overall & 91.25 & 92.65 & 97.5 & 77.94 \\
\hline \multicolumn{5}{|l|}{ Panel B } \\
\hline & \multicolumn{2}{|c|}{$\begin{array}{l}\text { Model } 10 \text { with Industry- } \\
\text { Relative Ratios }\end{array}$} & \multicolumn{2}{|c|}{$\begin{array}{l}\text { Model Created only with Equation } \\
\text { (8) and Industry-Relative Ratios }{ }^{b}\end{array}$} \\
\hline & $\begin{array}{l}\text { In-sample, } \\
\text { 1989-2003 }\end{array}$ & $\begin{array}{l}\text { Out-of-sample, } \\
2004-2012\end{array}$ & $\begin{array}{l}\text { In-sample, } \\
\text { 1989-2003 }\end{array}$ & $\begin{array}{l}\text { Out-of-sample, 2004- } \\
2012\end{array}$ \\
\hline Failures & 87.50 & 67.65 & 97.50 & 79.41 \\
\hline Survivors & 77.50 & 73.53 & 90.00 & 76.47 \\
\hline Overall & 82.50 & 70.59 & 93.75 & 77.94 \\
\hline
\end{tabular}

\section{Table 6: Classification validation results}

Note: The cut-off point is 0.500 .

a Bankruptcy classification model,

$\operatorname{Pr}_{i}=1 /\left(1+\exp -\left(0.022-4.724 X_{E / T D}+0.829 X_{D O L}-0.001 X_{N I}+0.798 X_{F D E P S}+7.798 X_{O E / S}\right)\right)$, created without combining equations (1) to (7), where Nagelkerke $R^{2}=0.926, \mathrm{E} / \mathrm{TD}=$ equity to total debt, $\mathrm{DOL}=$ degree of operation leverage, $\mathrm{NI}$ $=$ net income from continuing operations, FDEPS $=$ fully diluted EPS, and OE $/ \mathrm{S}=$ operating expense to sales.

b Bankruptcy classification model,

$\operatorname{Pr}_{i}=1 /\left(1+\exp -\left(1.528+6.557 X_{C R}-1.352 X_{A R T}-10.416 X_{E / T D}-0.209 X_{G P M}+0.458 X_{D E / S}-2.862 X_{C / C L}\right)\right)$, created with IRR but without combining equations (1) to (7), where Nagelkerke $R^{2}=0.859, \mathrm{CR}=$ current ratio, ART = accounts receivable turnover, $\mathrm{E} / \mathrm{TD}=$ equity to total debt, GPM = gross profit margin, $\mathrm{DE} / \mathrm{S}=$ depreciation expenses as a percent of sales, and $\mathrm{C} / \mathrm{CL}=$ cash to current liabilities.

Source: Own calculations.

The results of this out-of-sample test are indeed impressive and comparable to previous bankruptcy studies in Taiwan and elsewhere. Specifically, the type I accuracy only slightly 
decreases from $95.00 \%$ to $94.12 \%$, whilst the overall accuracy slightly increases from $91.25 \%$ to $92.65 \%$, indicating that our mathematical modeling procedure is not sensitive to differential industry effects and time variations.

To evaluate predictive performance of our bankruptcy classification model, we compares its results with the classification results from a recent bankruptcy study from Chen (2014) who combined PCA, Particle Swarm Optimization (PSO), and SVM to develop a complex hybrid bankruptcy-classification model. Chen (2014) used 24 matched pairs of bankrupt and nonbankrupt Taiwanese public industrial firms from 1999-2006 construct their hybrid model and 10 matched pairs from the same period as a holdout sample to validate their model. The respective in-sample and out-of-sample overall correct classifications of their hybrid model are $100.00 \%$ and $72.50 \%$ one year before bankruptcy. ${ }^{6}$

In contrast, our bankruptcy model' overall out-of-sample classification accuracy is $92.65 \%$ one year before bankruptcy, which outperforms Chen's (2014) $72.50 \%$ one year before bankruptcy. In addition, compared to Chen's (2014) bankruptcy model, our model is based on a considerably longer period (1989-2012 versus 1999-2006) and larger sample size (148 firms versus 68 firms).

To further assess the effectiveness of the proposed mathematical modeling procedure, we compare its results with the classification results from the bankruptcy model created only with hierarchical logistic-regression analyses (equation 8) by a maximum Nagelkerke $\mathrm{R}$-squared improvement procedure. As the right-hand side of Panel A of Table 6 shows, the respective Type I, Type II, and overall in-sample (out-of-sample) classification accuracy are $97.50 \%$ (73.53\%), 97.50\% (82.53\%), and $97.50 \%$ (77.94\%), showing a considerable difference between the in-sample and out-of-sample classification accuracy. This strongly suggests that bankruptcy models solely based on logistic-regression analyses are sensitive to differential industry effects and time variations.

In particular, whilst prior studies (e.g., Altman and Izan, 1983; Izan, 1984; Platt and Platt, $1990,1991)$ propose using industry-relative ratios to control for industry and time variations, they demonstrate significantly better out-of-sample classification results for corporate bankruptcy models using industry-relative ratios. Thus, to assess how well our

\footnotetext{
${ }^{6}$ Several older bankruptcy studies in Taiwan also demonstrate the ability of correctly classifying companies as likely to fail or not, despite relatively short study periods. For example, Lee and Yeh (2004) develop a logit financial distress prediction model based on the percentage of directors occupied by the controlling shareholder, the percentage the controlling shareholders shareholding pledged for bank loans (pledge ratio), and the deviation in control away from the cash flow rights. Their sample of companies failed during the four-year period, 1996-1999; the overall correct classification accuracy one year prior to failure from their logit model is $82.23 \%$. Lin (2009) who employs multiple discriminate analysis (MDA), logit, probit, and artificial neural networks (ANNs) methodology to develop financial distress prediction models. He demonstrates that the ANN approach achieves higher prediction accuracy when the data does not satisfy the assumptions of the statistical approach. His sample of companies failed during the eightyear period, covering $1998-2005$. The overall correct classification of his ANN model is $86.68 \%$ one year before bankruptcy..
} 
model decouples from differential industry effects and data instability over time, we performed industry-relative analysis. We compare its results with two scenarios: The model specification was not changed, and the model created with hierarchical logisticregression analyses (equation 8) by a maximum Nagelkerke R-squared improvement procedure.

Panel B of Table 6 reports the classification results of the models using industry-relative ratios. The respective Type I, Type II, and overall in-sample (out-of-sample) classification accuracy of Model 10 are $87.50 \%$ (67.65\%), 77.50\% (73.53\%), and $82.50 \%(70.59 \%)$, and those of the model created with equation (8) are $97.50 \%(79.41 \%), 90.00 \%(76.47 \%)$, and $93.75 \%(77.94 \%)$. The results show that not only is the overall out-of-sample classification accuracy with industry-relative ratios much lower, but the difference between in-sample and out-of-sample classification results with industry-relative ratios is considerably larger. This suggests that the proposed modeling approach appears to be more robust and is relatively insensitive to differential industry effects and time variations.

\section{Discussion}

Although considerable studies on the development of corporate bankruptcy prediction models have been reported; however, these studies predominantly focus on bankruptcy predictions in North America and Europe (e.g., Bandopadhyaya and Jaggia, 2001; Charitou et al., 2013; Johnsen and Melicher, 1994; Ohlson, 1980). In particular, previous studies suggest significant differences in corporate governance between East Asia and North America and Europe (e.g., Claessens et al., 2000; La Porta et al., 1999; Yeh et al., 2001). Accordingly, bankruptcy prediction models derived from samples of corporations in North America and Europe may not be applicable in East Asia.

While several recent studies in Taiwan have developed bankruptcy prediction models (e.g., Chen, 2014; Lin et al., 2013; Tsai, 2012), the validation results of testing the predictive ability of these models are somewhat disappointing. Likely explanations of the low predictive ability include significant differential industry effects due to a wide crosssection of industrial sectors with a relatively small number of companies per sector in Taiwan as well as financial data instability over time.

To fill this gap, we empirically examine the predictive ability of 60 financial ratios for bankruptcy predictions. A step-by-step mathematical modeling procedure that combines confirmatory factor analysis and logistic regression analysis was then proposed to develop bankruptcy prediction models. The empirical results indicate that the optimal bankruptcy model possesses a high prediction accuracy. The prediction rates are stable across industry sectors over time, as shown by relatively similar in-sample and out-ofsample classification results. 
The proposed mathematical modeling procedure improves the predictive ability of the logit bankruptcy model. A likely explanation for this improvement is that the performancemeasurement theory based on confirmatory factor analysis is able to help exclude those financial ratios that are susceptible to differential industry effects and data instability over time and, thus, provides a valid, stable factor solution for bankruptcy model development. This result has an important implication for empirical studies in other areas of finance, such as examining the relationship between financial ratios and market performance, analyzing the behavior of financial ratios, assessing the effects of merger on financial performance, and evaluating the effects of strategic investment on corporate performance. More specifically, the performance-measurement theory should be integrated into corporate financial and investment policymaking. This integration would provide valid, stable factor solutions, which in turn reduces the chance of obtaining spurious relationships and enhances the effectiveness of corporate financial and investment policymaking.

In addition, when assessing the effectiveness of the logit bankruptcy models, the optimal bankruptcy model is Model 10 that includes the five different aspects of financial conditions. Thus, another managerial policy implication is that these five different aspects, including short-term liquidity performance, capital structure and solvency, profitability performance, and cash flow performance, should all serve as key performance indicators of bankruptcy analysis for bankruptcy policymaking.

\section{Conclusion}

This study develops a bankruptcy classification model combining financial ratio analysis and measurement theory from a sample of 148 bankrupt and non-bankrupt companies between 1989 and 2012 in Taiwan. Firm financial ratios are combined into a bankruptcy performance-measurement model, which is then developed into a 10 variable, logit bankruptcy model. The model possesses high classification accuracy and relatively small differences in classification rates between in-sample and out-of-sample as compared to industry-relative analysis. The model appears to be robust across a broad range of firms and industries. The proposed mathematical modeling procedure based on measurement theory and hierarchical logistic-regression analysis appears to be especially appealing for bankruptcy models where companies represent a wide cross-section of industries.

\section{Acknowledgments}

We would like to thank the Ministry of Science and Technology of Taiwan ROC for financially supporting this research. 


\section{References}

Agarwal, V. and Taffler, R. J. (2008) Comparing the performance of market-based and accounting-based bankruptcy prediction models. Journal of Banking and Finance 32(8): 1541-1551. https://doi.org/10.1016/j.jbankfin.2007.07.014

Altman, E. I. (1968) Financial ratios, discriminant analysis and the prediction of corporate bankruptcy. Journal of Finance 23(4): 589-609. https://doi.org/10.1111/j.1540-6261.1968.tb00843.x

Altman, E. I., Haldeman, R. G. and Narayanan, P. (1977) ZETATM analysis: A new model to identify bankruptcy risk of corporations. Journal of Banking and Finance 1(1): 29-54. https://doi.org/10.1016/0378-4266(77)90017-6

Altman, E. I. and Izan, H. Y. (1983) Identifying corporate distress in Australia: An industry relative analysis. Australian Graduate School of Management.

Arena, M. (2008) Bank failures and bank fundamentals: A comparative analysis of Latin America and East Asia during the nineties using bank-level data. Journal of Banking and Finance 32(2): 299-310. https://doi.org/10.1016/j.jbankfin.2007.03.011

Balcaen, S. and Ooghe, H. (2006) 35 years of studies on business failure an overview of the classic statistical methodologies and their related problems. The British Accounting Review 38: 63-93. https://doi.org/10.1016/j.bar.2005.09.001

Bandopadhyaya, A. and Jaggia, S. (2001) An analysis of second time around bankruptcies using split population duration models. Journal of Empirical Finance 8(2): 201-218. https://doi.org/10.1016/S0927-5398(01)00023-8

Beaver, W. H. (1966) Financial ratios as predictors of failure. Journal of Accounting Research 4: 71-111. https://doi.org/10.2307/2490171

Becchetti, L. and Jaime, S. (2003) Bankruptcy risk and productive efficiency in manufacturing firms. Journal of Banking and Finance 27(11): 2099-2120. https://doi.org/10.1016/S0378-4266(02)00319-9

Bentler, P. M. (1990) Comparative fit indexes in structural models. Psychological Bulletin 107(2): 238-246. https://doi.org/10.1037/0033-2909.107.2.238

Casey, C. and Bartczak, N. (1985) Using operating cash flow data to predict financial distress: Some extensions. Journal of Account Research 23(1): 385-401. https://doi.org/10.2307/2490926

Castanias, R. (1983) Bankruptcy risk and optimal capital structure. Journal of Finance 38(5): 1617-35. https://doi.org/10.1111/j.1540-6261.1983.tb03845.x

Chandra, D.K., Ravi, V. and Bose, I. (2009) Failure prediction of dotcom companies using hybrid intelligent techniques. Expert Systems with Applications 36(3): 4830-4837. https://doi.org/10.1016/j.eswa.2008.05.047

Charitou A., Dionysiou D., Lambertides N. and Trigeorgis L. (2013) Alternative bankruptcy prediction models using option-pricing theory. Journal of Banking and Finance 37(7): 2329-2341. https://doi.org/10.1016/j.jbankfin.2013.01.020 
Charitou, A., Neophytou, E. and Charalambous, C. (2004) Predicting corporate failure: Empirical evidence for the UK. European Account Review 13(3): 465-497. https://doi.org/10.1080/0963818042000216811

Chen, M.Y. (2014) Using a hybrid evolution approach to forecast financial failures for Taiwan-listed companies. Quantitative Finance 14( 6): 1047-1058. https://doi.org/10.1080/14697688.2011.618458

Claessens, S., Djankov, S. and Klapper, L. (2003) Resolution of corporate distress in East Asia. Journal of Empirical Finance 10(1-2): 199-216. https://doi.org/10.1016/S0927-5398(02)00023-3

Claessens, S., Djankov, S. and Lang, L.H.P. (2000) The separation of ownership and control in East Asian corporation. Journal of Financial Economics 58 (1-2): 81-112. https://doi.org/10.1016/S0304405X(00)00067-2

Dambolena, I. G. and Khoury, S. J. (1980) Ratio stability and corporate failure. Journal of Finance 35(4): 1017-1026. https://doi.org/10.1111/j.1540-6261.1980.tb03517.x

du Jardin, P. (2016) A two-stage classification technique for bankruptcy prediction. European Journal of Operational Research 254(1): 236-252. https://doi.org/10.1016/j.ejor.2016.03.008

Evans, J. (2003) The effect of discretionary actions on small firms' ability to survive chapter 11 bankruptcy. Journal of Corporate Finance 9(1): 115-128. https://doi.org/10.1016/S0929-1199(01)00052-9

Foreman, R. D. (2003) A logistic analysis of bankruptcy within the US local telecommunications industry. Journal of Economics and Business 55(2): 135-166. https://doi.org/10.1016/S0148-6195(02)00133-9

Fornell, C., Larcker, D. F. (1981) Evaluating structural equation model with unobservable variables and measurement error. Journal of Marketing Research 18(1): 39-50. https://doi.org/10.2307/3151312

Frohlich, M. T. (2002) E-integration in the supply chain: barriers and performance. Decision Sciences 33(4): 537-56. https://doi.org/10.1111/j.1540-5915.2002.tb01655.x

Frydman, H. and Altman, E. I. Kao, D. (1985) Introducing recursive partitioning for financial classification: The case of financial distress. Journal of Finance 40(1): 269-291. https://doi.org/10.1111/j.15406261.1985.tb04949.x

Harrington, D. (2008) Confirmatory Factor Analysis. New York: Oxford University Press. https://doi.org/10.1093/acprof:oso/9780195339888.001.0001

Hair, J. F., Black, W. C., Babin, B. J. and Anderson, R. E. (2009) Multivariate Data Analysis. Hoboken, NJ: Prentice Hall.

Izan, H. Y. (1984) Corporate distress in Australia. Journal of Banking and Finance 8(2): 303-20. https://doi.org/10.1016/0378-4266(84)90010-4

Johnsen, T. and Melicher, R. W. (1994) Predicting corporate bankruptcy and financial distress: Information value added by multinomial logit models. Journal of Economics and Business 46(4): 269-286. https://doi.org/10.1016/0148-6195(94)90038-8

Karels, G. and Prakash, A. (1987) Multivariate normality and forecasting of business bankruptcy. Journal of Business Finance and Accounting 14(4): 573-595. https://doi.org/10.1111/j.14685957.1987.tb00113.x 
Kim, Y. and Nabar, S. (2007) Bankruptcy probability changes and the differential informativeness of bond upgrades and downgrades. Journal of Banking and Finance 31(12): 3843-3861. https://doi.org/10.1016/j.jbankfin.2007.02.008

Kline, R. B. (2010) Principles and practice of structural equation modeling. New York: The Guilford Press.

Lam, M. (2004) Neural networks techniques for financial performance prediction: Integrating fundamental and technical analysis. Decision Support Systems 37, 567-581. https://doi.org/10.1016/S01679236(03)00088-5

La Porta, R., Lopez-de-Silanes, F. and Shleifer, A. (1999) Corporate ownership around the world. Journal of Finance 54(2): 471-517. https://doi.org/10.1111/0022-1082.00115

Lee, S.Y. (2007) Structural equation modelling: A Bayesian approach. West Sussex: John Wiley \& Sons. https://doi.org/10.1002/9780470024737

Lee, T. S. and Yeh, Y. H. (2004). Corporate governance and financial distress: Evidence from Taiwan. Corporate governance: An international review, 12(3): 378-388. https://doi.org/10.1111/j.14678683.2004.00379.x

Li, M. Y. L. and Miu, P. (2010) A hybrid bankruptcy prediction model with dynamic loadings on accountingratio-based and market-based information: A binary quantile regression approach. Journal of Empirical Finance 17(4): 818-833. https://doi.org/10.1016/j.jempfin.2010.04.004

Liang, D., Lu, C.C., Tsai, C. F. and Shih, G. A. (2016) Financial ratios and corporate governance indicators in bankruptcy prediction: A comprehensive study. European Journal of Operational Research 252(2): 561-572. https://doi.org/10.1016/j.ejor.2016.01.012

Lin F., Yeh, C. C. and Lee, Y. M. (2013) A hybrid business failure prediction model using locally linear embedding and support vector machines. Romanian Journal of Economic Forecasting 16(1): 82-97.

Lin, T. H. (2009). A cross model study of corporate financial distress prediction in Taiwan: Multiple discriminant analysis, logit, probit and neural networks models. Neurocomputing, 72(16): 3507-3516. https://doi.org/10.1016/j.neucom.2009.02.018

Mensah, Y. M. (1984) An examination of the stationarity of multivariate bankruptcy prediction models: A methodological study. Journal of Accounting Research 22(1): 380-395. https://doi.org/10.2307/2490719

Merton, R. C. (1974) On the pricing of corporate debt: The risk structure of interest rates. Journal of Finance 29, 449-470.

Ohlson, J. (1980) Financial ratios and the probabilistic prediction of bankruptcy. Journal of Accounting Research 18(1): 109-131. https://doi.org/10.2307/2490395

Ouenniche, J. and Tone, K. (2017) An out-of-sample evaluation framework for DEA with application in bankruptcy prediction. Annals of Operations Research 249(1): 1-16. https://doi.org/10.1007/s10479017-2431-5

Platt, H. D. and Platt, M. B. (1990) Development of a class of stable predictive variables: The case of bankruptcy prediction. Journal of Business Finance and Accounting 17(1): 31-51. https://doi.org/10.1111/j.1468-5957.1990.tb00548.x 
Platt, H. D. and Platt., M. B. (1991) A note on the use of industry-relative ratios in bankruptcy prediction. Journal of Banking and Finance 15(6): 1183-1194. https://doi.org/10.1016/0378-4266(91)90057-S

Pompe, P. P. and Bilderbeek, J. (2005) The prediction of bankruptcy of small- and medium-sized industrial firms. Journal of Business Venturing 20(6): 847-868. https://doi.org/10.1016/j.jbusvent.2004.07.003

Tsai, B. H. (2012) Comparison of binary logit model and multinomial logit model in predicting corporate failure. Review of Economics and Finance 2(4): 99-111.

Wallace, L., Keil, M. and Rai, A. (2004) How software project risk affects project performance: an investigation of the dimensions of risk and an exploratory model. Decision Sciences 35(2): 289-321. https://doi.org/10.1111/j.00117315.2004.02059.x

Yeh, Y. H., Lee, T. S. and Woidtke, T. (2001) Family control and corporate governance: Evidence for Taiwan. International Review of Finance 2(3): 21-48. https://doi.org/10.1111/1468-2443.00014

Zavgren, C. (1983) The prediction of corporate failure: the state of the art. Journal of Accounting Literature 2(1): $1-37$.

Zavgren, C. V. (1985) Assessing the vulnerability to failure of American industrial firms: A logistic analysis. Journal of Business Finance and Accounting 12(1): 19-45. https://doi.org/10.1111/j.14685957.1985.tb00077.x 